\title{
FENOMENA CAPTION “TWITTER, PLEASE DO YOUR MAGIC!” MEMBANGKITKAN NETIZEN UNTUK MENOLONG
}

\author{
Nahdah Salsabila Fammy ${ }^{(1)}$, Dr. Aa Bambang ${ }^{(2)}$, Dian Tri Hapsari, M.Si ${ }^{(3)}$ \\ Program Studi Ilmu Komunikasi, FISIP Universitas Pembangunan Nasional "Veteran” Jakarta \\ Jalan R.S Fatmawati, Pangkalan Jati, Cilandak, Cinere, Kota Jakarta Selatan, Jawa Barat I65 I 4 \\ Email: (I) salsabilanahdah5@gmail.com, (2) aa_saputera2@hotmail.com, (3) diantrihapsari@upnvj.ac.id
}

\begin{abstract}
Abstrak
This research discusses the social media Twitter, which can arouse awareness, and the context of sharing, which can make a tweet become viral and hotly discussed by many people, especially Twitter netizens. The writing of this article is motivated by the large number of social media users who tend to lead to bad or negative actions. For this reason, the purpose of this study is to provide an explanation that Twitter's social media can inspire young people to provide information that is not only important, but also provides profound and useful meaning. This study uses qualitative research methods and phenomenological theory as the basis. Then use interview techniques in gathering data. Based on the results of this study, the authors suggest, Twitter can be one of the social media that directs positive things to the general public, not only with the action please help, but also by doing other things better that can be followed by media users other social, especially in the younger generation.
\end{abstract}

Keywords : Twitter, netizen, sharing.

\section{PENDAHULUAN}

Internet menjadi salah satu media yang saat ini sangat dibutuhkan oleh masyarakat. Dalam berbagai hal, internet mampu memberikan kemudahan bagi penggunanya untuk mencari dan berbagi informasi. Siapa saja dan di mana pun dapat mengakses internet. Dengan kecanggihan yang ditawarkan, internet menjadi pilihan utama untuk memperoleh berbagai macam informasi, mulai dari dalam negeri hingga ke luar negeri. Internet digunakan tidak hanya pada kalangan dewasa saja tetapi juga anak remaja bahkan anak di bawah umur juga menggunakan jaringan internet dalam melakukan segala aktivitasnya, baik digunakan untuk memperoleh kebutuhan informasi maupun kebutuhan hiburan semata.

Survei Asosiasi Penyelenggaraan Jasa Internet Indonesia (APJII) menyebutkan bahwa terobosan pengguna internet di Indonesia meningkat menjadi 143,26 juta jiwa atau setara 54,7 persen dari total populasi di Indonesia. Survei serupa pada tahun 2016 menunjukkan, jumlah pengguna internet Indonesia mencapai 132,7 juta jiwa. Hasil survei ini telah membuktikan bahwa penggunaan media internet sangat luas, bahkan lebih dari setengah populasi di Indonesia. Antusiasme masyarakat Indonesia begitu besar terhadap keberadaan internet. Jaringan internet sangat memudahkan mobilitas masyarakat Indonesia, khususnya dalam berinteraksi dan juga memperoleh informasi yang beragam. 
Twitter menjadi salah satu media sosial yang saat ini tidak kalah penggunaannya dengan media sosial lainnya seperti Instagram. Media sosial yang satu ini juga tengah digandrungi kembali setelah sebelumnya sempat populer di tahun 2011. Kali ini media sosial Twitter kembali digunakan oleh penggunanya, khususnya di kalangan remaja. Dengan adanya Twitter, sebuah peristiwa dapat menjadi sebuah fenomena yang viral apabila mendapat banyak perhatian dari pengguna media sosial Twitter.

Namun, informasi yang dihadirkan harus memiliki nilai yang penting dan menarik. Penting dan menarik itu tentu saja relatif dan membutuhkan intuisi yang terlatih. Secara teoritis, ada delapan aspek dalam menyusun nilai berita, yaitu kebaruan, pengaruh, relevansi, konflik, popularitas, emosi, ketidakwajaran, dan kedekatan jarak. (Wendratama, 2017, 44)

Peristiwa atau tindakan dari seseorang mudah disoroti terutama apabila tindakan tersebut memiliki hal yang positif atau hal yang perlu ditiru, salah satunya yaitu tindakan tolong-menolong. Saling membantu orang lain merupakan tindakan yang sangat terpuji. Twitter seakan tidak lagi hanya digunakan sebatas untuk berbagi cerita berupa tulisan masalah atau kejadian pribadi, tetapi media sosial yang satu ini juga dapat digunakan untuk saling membantu, mulai dari hal kecil seperti meminta bantuan warga Twitter untuk memberi retweet dan like agar kepentingan pemilik akun dapat terpenuhi hingga membantu menemukan pemilik barang berharga yang hilang serta membantu mempromosikan jualan pedagang kaki lima.

Sesuai dengan tema yang dipilih pada penelitian ini yaitu adanya unsur mencari dan mendapatkan informasi. Bagaimana sebuah informasi tersebut bisa sampai ke khalayak ramai yang jauh sekalipun. Kemudian, apakah media sosial twitter dapat mempengaruhi penggunanya untuk berbagi informasi? Dalam hal ini, masyarakat atau orang awam bisa berbagi informasi mengenai kejadian-kejadian yang dianggap penting dan menarik untuk dibagikan di media sosial, khususnya di media sosial twitter.

Bagaimana media sosial Twitter dapat memviralkan suatu fenomena yang terjadi di dunia maya, karena tanpa sadar hal atau fenomena yang diviralkan membuat pemilik akun tersebut secara tidak langsung memberikan informasi kepada masyarakat luas melalui media sosial Twitter? Mengapa harus media sosial Twitter? Serta apa yang dimaksud dengan tagline Twitter, please do your magic? Lalu bagaimana keterkaitan media sosial Twitter dengan penggunanya untuk menyebarluaskan sebuah informasi? Informasi tersebut juga bukan sembarang informasi melainkan informasi yang berisi tentang aksi tolong-menolong yang tentunya sangat positif dilakukan oleh banyak orang. Berdasarkan uraian di atas, penelitian ini bertujuan untuk mengetahui, apakah media sosial twitter bisa membuat penggunanya terdorong untuk menolong orang lain? Meskipun hanya dari tulisan yang dibagikan. Kemudian, untuk mengetahui bagaimana tindakan pengguna twitter dalam melakukan perbuatan tolong menolong dengan cara menyebarluaskan informasi yang mereka peroleh? Serta apa kepentingan netizen tersebut dalam membagikan informasi yang diterima melalui media sosial twitter.

Penelitian ini menggunakan teori fenomologi. Teori ini diambil karena berasumsi untuk memahami sebuah peristiwa dari pengalaman yang terjadi pada seorang individu.

Penelitian ini akan membahas mengenai bagaimana seseorang dapat memberikan informasi kepada orang lain untuk saling menolong. Hal ini didasari karena orang yang memberikan informasi ini melihat sebuah kejadian langsung dan merasa iba kemudian mem-post dan membagikan informasi tersebut kepada khalayak luas, yang diberikan di akun media sosialnya, yang secara tidak langsung mengubah peristiwa yang hadir menjadi sebuah pengalaman kepada diri sendiri. Pengalaman-pengalaman pribadi inilah yang kemudian 
memungkinkan adanya sudut pandang dari beberapa orang yang menyebarkan informasi dari akun pribadinya masing-masing dan kemudian disebarkan melalui media sosial Twitter dan menyita banyak perhatian warga internet lainnya, atau netizen, khususnya pada media sosial Twitter.

"Teori-teori dalam tradisi fenomenologi berasumsi bahwa orang-orang secara aktif menginterpretasi pengalaman-pengalamannya dan mencoba memahami dunia dengan pengalaman pribadinya" (John, 2009, 57).

\section{Studi Pustaka dan Kajian Teori}

Dalam jurnal Suzy Azeharie dan Octavia Kusuma dengan judul jurnal Analisis Pengguna Twitter sebagai Media Komunikasi Selebritis di Jakarta. Jurnal ini memiliki tujuan untuk mengetahui alasan serta kegunaan twitter sebagai media komunitas selebritis, yang mana hal ini cukup terikat dengan penulisan artikel ini. Hasil penelitian analisis ini menunjukkan bahwa alasan Indra Aziz, Pongki Barata dan Kerispatih memilih twitter karena penggunannya lebih mudah jika dibandingkan dengan media sosial lainnya. Penggunaan twitter dinilai sangat efektif karena para selebritis dapat menyamaikan segala informasi yang ingin diberikan. Sama halnya dengan penulisan artikel ini, yaitu mengambil manfaat dari penggunaan media sosial twitter. Kemudian untuk teori yang digunakan pada pernulisan artikel ini menggunakan teori fenomenologi. Pengambilan teori ini karena teori ini berasumsi untuk memahami sebuah peristiwa dari pengalaman yang terjadi pada seorang individu. Teori fenomenologi menjabarkan serta mempelajari bentuk pengalaman dari sudut pandang orang yang mengalaminya langsung dan juga struktur pengalaman sadar dari seorang individu.

\section{METODE PENELITIAN}

Pengumpulan data pada penulisan penelitian ini menggunakan teknik wawancara yang melibatkan beberapa responden sebagai narasumber yang nantinya akan dimintai keterangan mengenai fenomena yang terjadi di dalam media sosial Twitter. Wawancara sendiri dibagi dua yaitu wawancara terstruktur dan tak terstruktur. Wawancara terstruktur sering juga disebut wawancara baku, yang susunan pertanyaannya sudah diterapkan sebelumnya dengan pilihan-pilihan jawaban yang juga sudah disediakan sedangkan wawancara tak berstruktur sering juga disebut wawancara mendalam, wawncara intensif, wawancara kualitatif, dan wawancara terbuka. (Mulyana, 2008, 180)

Dari kedua jenis wawancara tersebut, yang akan digunakan pada penulisan penelitian ini adalah wawancara tak terstruktur, karena wawancara ini dirasa lebih tepat untuk menjabarkan pokok permasalahan yang terjadi di media sosial, khususnya Twitter, untuk menggali informasi mengenai fenomena caption "Twitter, please do your magic!". Narasumber berupa netizen Twitter akan diberikan beberapa pertanyaan terkait penggunaan caption fenomenal Twitter tersebut untuk membantu sesama.

Pendekatan penelitian kualitatif lebih menekan pada prinsip-prinsip umum yang terjadi dalam keseharian masyarakat. Pendekaatan kualitatif juga menjelaskan suatu gejala dengan keadaan yang alamiah, yang artinya murni terjadi di masyarakat dan fakta yang ada di lapanganlah yang menjadi acuan dalam penulisan penelitian ini sehingga pendekatan inilah yang cocok dengan tema yang diangkat: memberikan suatu infromasi yang ada di sekitarnya untuk diketahui khalayak luas melalui media sosial Twitter dengan menggunakan caption "Twitter, please do your magic!" agar lebih mudah mendapat perhatian dari pembaca tulisan tersebut. 


\section{HASIL DAN PEMBAHASAN}

Fokus penelitian ini juga tidak sebatas diangkat karena menarik saja, namun hal ini perlu dan penting mengingat penggunaan media sosial saat ini semakin banyak menimbulkan dampak-dampak yang buruk. Salah satunya adalah pengguna media sosial menjadi memiliki sifat yang individualistis. Adanya sikap ini memicu dampak yang kurang baik untuk masyakarat serta lingkungan dari pengguna itu sendiri. Pengguna media sosial tersebut tidak peduli dengan lingkungan sekitarnya dan cenderung mementingkan diri sendiri. Namun, tema yang diambil ini mengangkat sisi positif penggunaan media sosial terhadap penggunanya, yaitu menggunakan media sosial dengan bijak dengan cara membantu orang di sekitar kita.

Tema ini dapat dikatakan penting karena memiliki tujuan yang positif yaitu untuk menyadarkan kita begitu pentingnya saling peduli dan saling tolong-menolong membantu sesama manusia di sekitar kita, sekalipun kita tidak saling mengenal. Bahkan dengan adanya media sosial, jarak dan waktu bukan menjadi alasan lagi bagi kita untuk saling membantu karena hanya dengan sharing atau menyebarkan informasi mengenai hal untuk tolongmenolong pun, kita sudah termasuk membantu orang yang membutuhkan bantuan. Selain itu, pengguna media sosial twitter mempunyai alasan utama untuk mengangkat tema ini, karena kebanyakan warga twitter menggunakan caption “Twitter please do your magic!" tujuannya untuk menolong orang lain.

Terkait dengan fenomena media sosial Twitter di Indonesia, caption "Twitter, please do your magic!" cukup populer. Ada banyak tema beragam untuk mencari bantuan di media sosial Twitter dengan harapan banyak yang ikut men-share dengan cara me-retweet, me-like, dan juga berkomentar tentang informasi yang ada di media sosial Twitter. Mengutip detik.com, Dwi Ardiansah selaku Country Industry Head Twitter Indonesia dan Malaysia menanggapi tagline fenomena Twitter ini.

"Kalau kita lihat mulai dari orang di pinggir jalan dan ingin dibantu, sampai pengguna ingin dibantu, biasanya keywordnya “Twitter please do your magic," ujar Dwi selaku CEO Twitter Indonesia dan Malaysia.

Dari data yang dimiliki oleh Twitter, ada tiga hal yang banyak dilakukan pengguna twitter, yaitu: $32 \%$ pengguna datang ke Twitter karena ingin menemukan hal yang baru, kemudian sebanyak $26 \%$ untuk mencari informasi, dan $16 \%$ untuk hal lainnya seperti mencari cerita menarik.

Namun, tidak semua pengguna atau netizen Twitter menggunakan caption fenomenal Twitter ini untuk tujuan atau kepentingan orang lain, melainkan untuk kepentingan pribadi. Media sosial Twitter juga dirasa menguasai kecepatan dalam penyebarannya. Dengan fitur like dan retweet pula, netizen lain yang turut membaca post untuk membantu masyarakat sekitar secara tidak langsung turut membantu dengan menyebar luaskan atau sharing kembali informasi dari pemilik akun media sosial Twitter pertama penyebar informasi.

Berikut merupakan hasil dari penelitian yang dilakukan pada netizen Twitter Alfioni Salsabila (@serahludahhh). Narasumber pertama yaitu Alfioni Salsabila dengan nama akun Twitter @serahludahhh. Ia merupakan seorang mahasiswi di sebuah Universitas di daerah Jakarta. Karena mendapat respon yang positif dan banyak dari netizen lainnya, mahasiswi ini pun sempat viral di beberapa platform atau portal media online karena ia dengan hati yang besar mau mengembalikan iPhone X milik seseorang yang ia temukan di Stasiun Cikini Jakarta. Seperti yang diketahui bahwa handphone yang mahasiswi ini temukan memiliki nilai yang cukup mahal sehingga orang lain mungkin berpikir dua kali untuk mengembalikan handphone bernilai belasan juta tersebut. Banyak juga dari netizen pengguna Twitter yang menggunakan Twitter dan melihat tweet milik Alfoni 
tersebut dan memuji aksi yang dilakukan oleh Alfoni terhadap orang lain yang tidak ia kenal. Bahkan tidak pernah bertemu sebelumnya.

Cuitan yang ditulis Alfoni ini banjir retweet dan like serta comment dari netizen Twitter. Begitu banyaknya respon dari netizen, Alfoni sempat diundang on air oleh Radio Prambors FM yang dibawakan oleh Desta dan Gina. Mahasiswi yang akrab dipanggil Alfi dan berusia 19 tahun ini menggunakan media Twitter untuk meminta tolong kepada netizen Twitter menemukan siapa pemilik iPhone tersebut. Post di akun media sosial pribadinya ini ditulis pada tanggal 13 Agustus 2019.

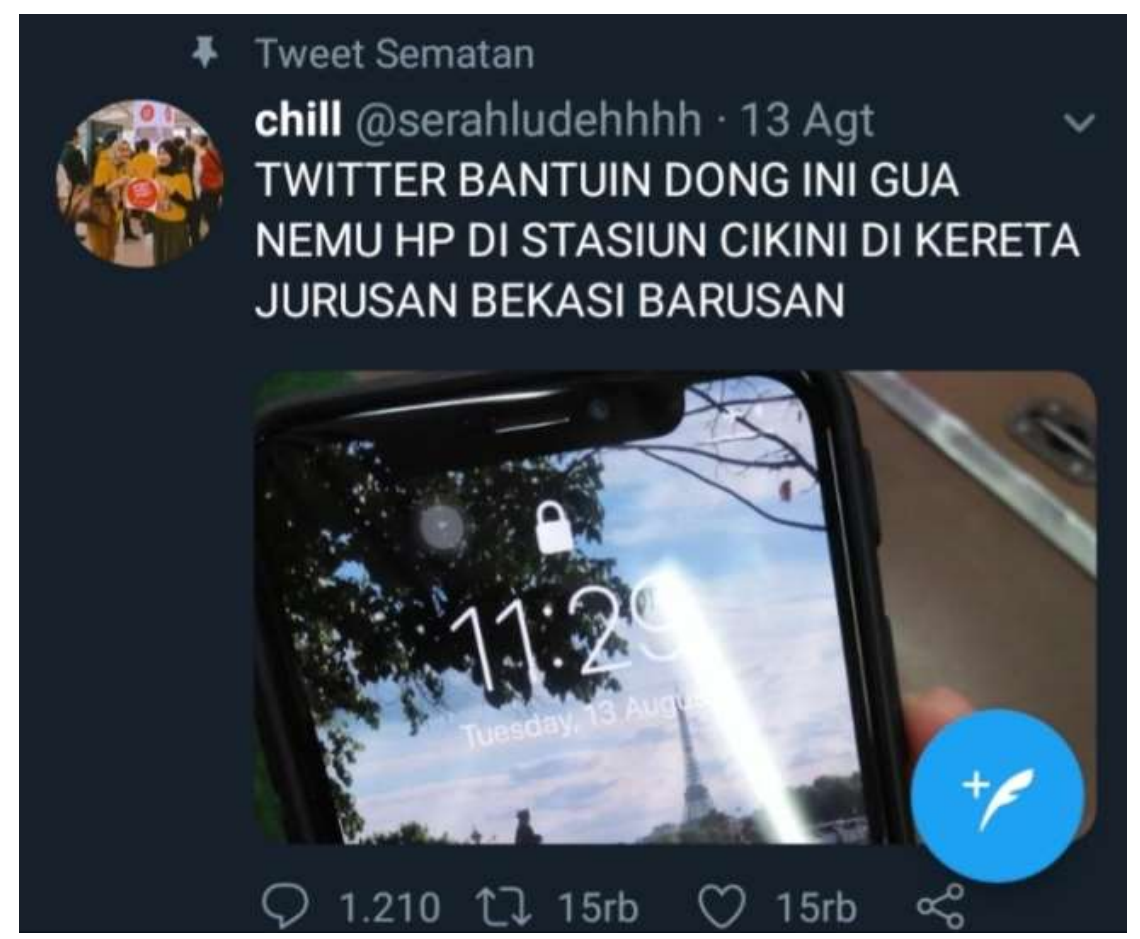

Gambar 1 Screenshot @ serahludehhhh

Alasan ia menggunakan media Twitter adalah karena sebelumnya ia banyak melihat tweet yang meminta bantuan di Twitter, dan berhasil. Sehingga ia pun ikut mencoba meminta bantuan di media sosial Twitter. Menurutnya pula media sosial Twitter memang paling cocok untuk menyebarkan informasi dibanding media sosial lainnya. Twitter menurutnya merupakan wadah penyebaran informasi dalam bentuk narasi maupun visual yang paling efektif.

Tujuan dari penyebaran informasi ini di akun media sosial Twitter miliknya adalah murni ingin menolong dan mencari pemilik asli hanpdphone yang cukup terkenal karena harganya yang cukup mahal tersebut. Niatnya yang tulus pun mengantarkannya untuk mendapat petunjuk-petunjuk agar segera menemukan pemilik asli handphone tersebut, yang tentunya petunjuk-pentunjuk tersebut diperolehnya dari netizen atau warga Twitter lainnya yang membaca post yang ia tulis tersebut.

"Niat saya mencuit itu sebenarnya murni untuk meminta bantuan untuk menyebarkan informasi tersebut dengan tujuan ada warga Twitter yang mengenal pemilik. Selain karena itu juga karena mengharapkan bantuan berupa petunjuk-petunjuk melacak informasi pribadi pemilik Iphonenya. memang setelah saya mencuit itu banyak sekali yang memberi bantuan berupa petunjuk-petunjuk seperti mengecek medical id pemilik iPhone." 
Alhasil, dari post tersebut, Alfoni berhasil menemukan pemilik handphone yang ia temui di stasiun tersebut. Sepanjang ia ingin menemukan pemilik dari hanpdhone tersebut, Alfoni terus men-share informasi kepada netizen yang turut penasaran bagaimana saat ia menemukan pemilik handphone tersebut.

Narasumber kedua yaitu netizen yang juga menggunakan caption "Twitter, Please do your magic!" adalah Annisa Widya Ariani atau akrab disapa Awe dengan akun Twitter @annisawdya ia menuturkan mulanya ia menulis cuitan dengan konteks untuk menolong setelah melihat post temannya di media sosial lain (Instagram). Pertama kali menemukan cuitan ini perhatiannya langsung tertuju pada caption dari awal kalimat cuitan ini, yaitu caption fenomenal di media sosial Twitter. Selain itu, tempat kejadian dari peristiwa yang berusaha narasumber rekam melalui akun media sosial temannya ini tidak terlalu jauh dari tempat tinggalnya di kawasan Bintaro, Tangerang Selatan. Awe sendiri tinggal di kawasan Jakarta Utara. Awe menuturkan bagaimana peristiwa ini terjadi. Bagaimana seorang pengendara ojek online ini harus mengalami nasib yang kurang beruntung karena motor untuk mencari nafkah dari Bapak di dalam video tersebut raib begitu saja. Padahal pengendara ojek online hanya meninggalkan motor tersebut sebentar. Video ini pun telah ditonton sebanyak 797 ribu kali oleh para netizen Twitter. 


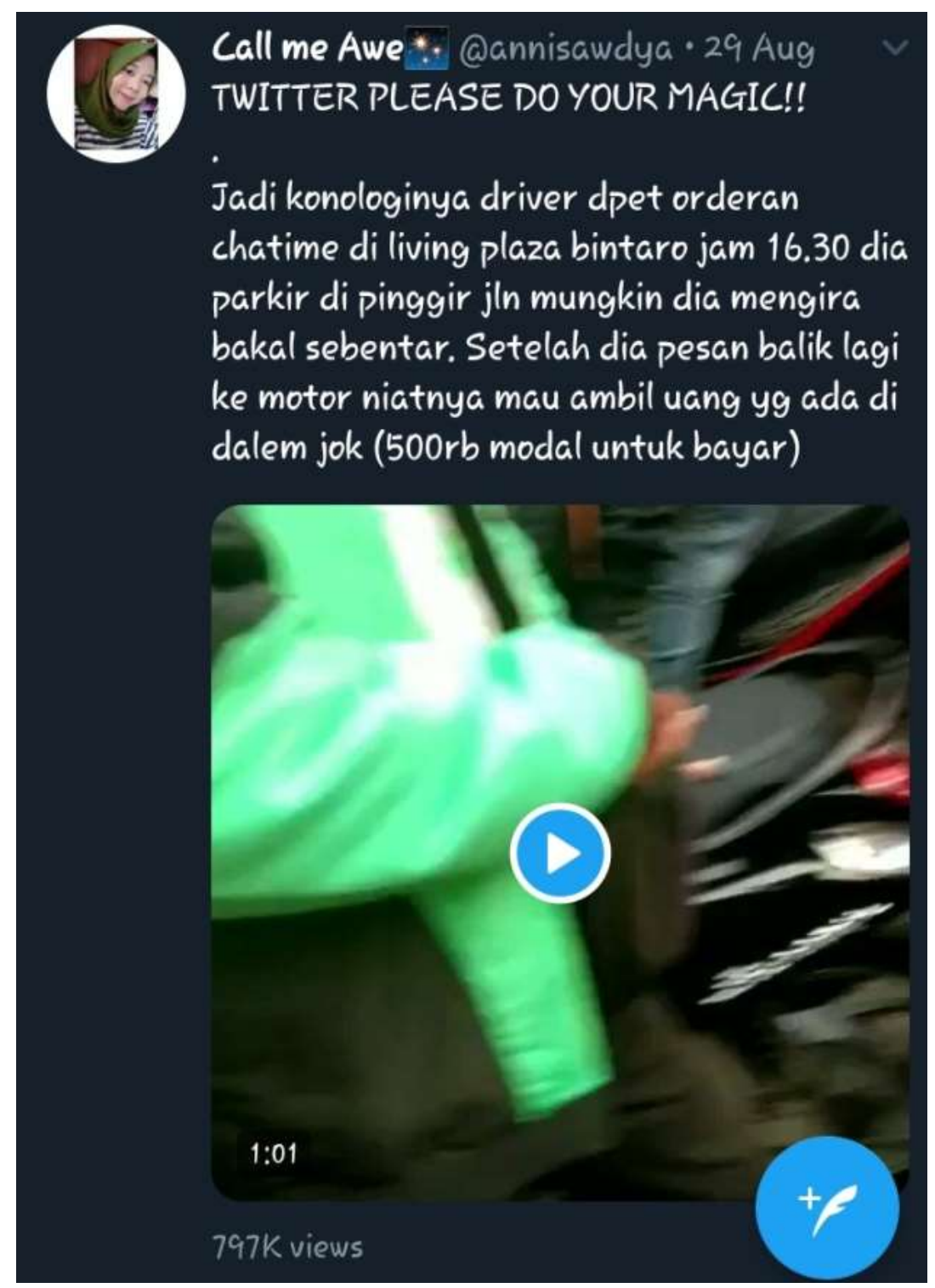

Gambar 2 Screenshot @annisawdya

Penggunaan media Twitter adalah untuk membantu men-share motor seorang driver ojek online yang hilang ia menyatakan bahwa pemilihan penggunaan Twitter adalah karena menurutnya penggunaan media sosial Twitter merupakan media yang penyebarannya efektif dan cepat. Hal tersebut pun terbukti dari respon netizen Twitter yang ikut me-retweet dan me-like post akun Twitter narasumber yang akrab dipanggil Awe sedangkan tujuan dari post tersebut ialah atas dasar kasihan, sedih, dan tidak tega saat melihat post dari temannya di media Instagram. Awe pun juga sempat menceritakan bahwa driver ojek online tersebut memiliki 4 (empat) anak di rumah yang masih mengontrak. Ia juga menuturkan perasaannya yang kadang kurang pandai bersyukur atas apa yang telah ia peroleh. Dari situlah Awe merasa terketuk pintu hatinya untuk menolong Bapak terebut.

Narasumber netizen Twitter yang menggunakan caption fenomenal Twitter berikutnya pada penelitian ini merupakan seorang anggota dari komunitas yang mendampingi korban yang ia post dalam tweet-nya menggunakan kalimat “Twitter, please do your magic!”. Dalam post ini, Alya Zulda Putri atau Alya menceritakan kondisi korban yang mengalami sakit akibat tindakan pedofil atau kejahatan seksual terhadap anak di bawah umur. Korban masih berusia 12 tahun. Sampai saat ini, pelaku belum tertangkap dan belum diketahui 
siapa pelakunya. Dalam post-nya juga, Alya mengatakan bahwa pelaku kabur setelah mengetahui korban mengalami pendarahan. Pelaku masih dalam masa pencarian. Tweet ini mendapat perhatian dari netizen Twitter lainnya sebanyak kurang lebih lima puluh dua ribu reweet dan tiga puluh satu ribu like serta seribu komen dari netizen Twitter yang melihat post Alya di akun media sosial pribadinya.

Penggunaan media sosial Twitter dipilih karena menurutnya media sosial Twitter memiliki perkembangan berita yang sangat cepat dibanding media sosial lainnya. Penggunaan media sosial Twitter juga dirasa sangat efektif dalam memperoleh sebuah informasi. Media sosial Twitter memiliki fitur yang memang berbeda dibanding dengan media sosial lainnnya, yaitu tidak mengedepankan visual tetapi lebih pada tulisan. Hal ini juga yang membuat Twitter menjadi salah satu media sosial yang sangat disukai karena kemudahan dan kepraktisan yang diperoleh di dalam aplikasi media sosial ini. Pengguna akan merasa fokus kepada isi dibanding dengan gambar yang di-post oleh penggunanya. Isi merupakan salah satu hal yang teramat penting, namun sering dilupakan oleh sebagian orang dalam menggunakan media sosial.

Penggunaan media sosial Twitter ini juga sejalan dengan tanggapan Vinta Sevilla, S.IIP., M.I.KOM selaku salah satu dosen Universitas Pembangunan Nasional "Veteran" Jakarta, terhadap penggunaan media sosial sebagai media untuk sharing tolong-menolong baginya, yang juga menggunakan media Twitter. Menurutnya, untuk tujuan sosial, efeknya terbilang sangat signifikan. Media sosial juga terlihat trasnparan karena hasil dan perkembangannya terus di-update oleh si pengguna akun Twitter yang menggunakannya untuk galang dana demi membantu sesama.

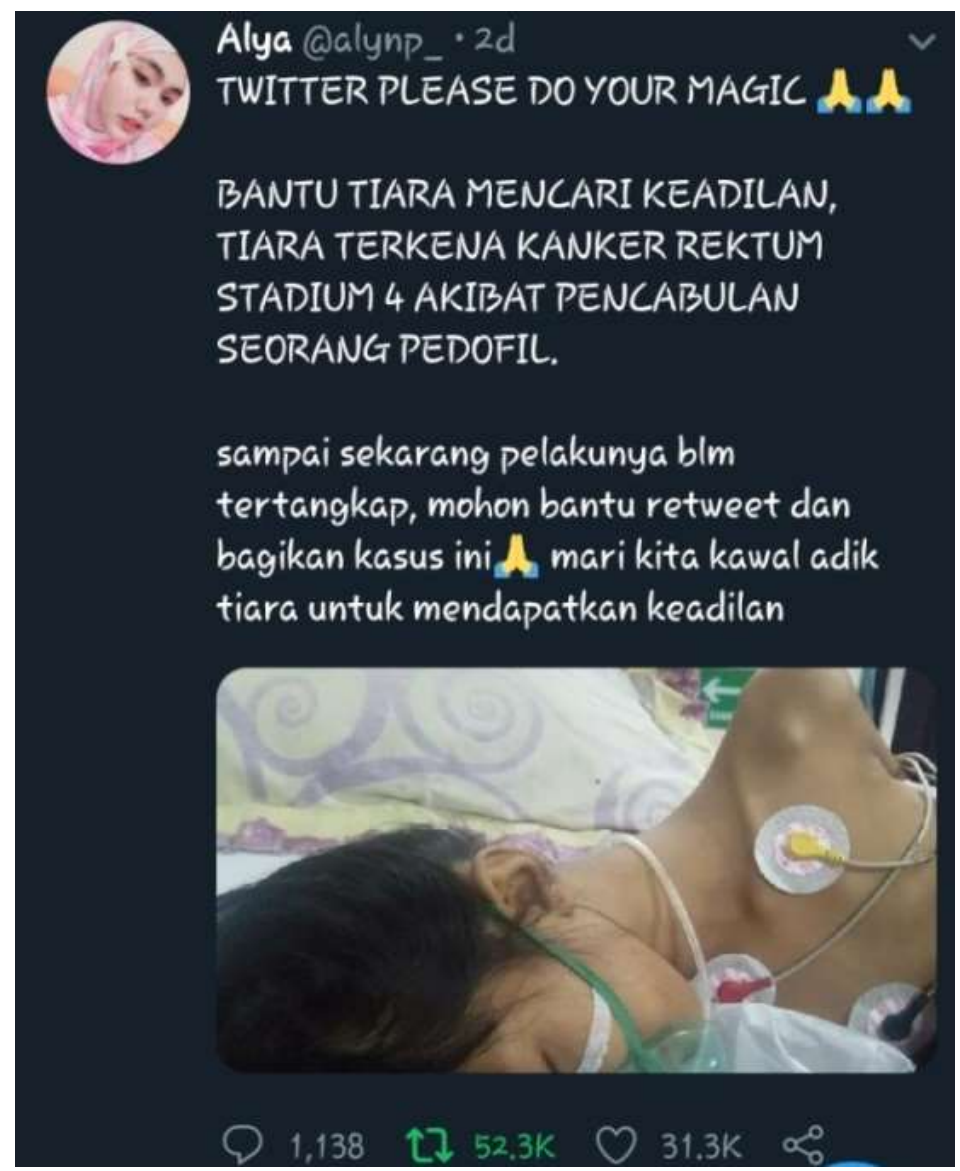

Gambar 3 Screenshot @alynp_ 
Dalam menulis cuitan menggunakan caption fenomenal Twitter, menurut Alya, ia tidak memiliki kepentingan pribadi atau kepentingan lainnya. Ia hanya memiliki tujuan yang murni ingin membantu korban dan dapat sesegera mungkin menangkap pelaku kejahatan seksual di bawah umur tersebut. Alya sendiri juga tidak memiliki ikatan keluarga maupun teman atau pun kenalan terhadap korban yang usianya masih 12 tahun (foto yang ada dalam gambar).

Hasil dari wawancara yang ada berkaitan dengan paradigma yang digunakan dalam penelitian ini, yaitu Paradigma Konstruktivisme, yang lebih menekankan kemampuan manusia sebagai individu untuk memahami dunia kehidupan atau dunia tempat mereka hidup dan beraktivitas serta mengembangkan berbagai makna subjektif berdasarkan pengamalam mereka (Putra, 2013, 16).

Hasil penelitian yang dilakukan pada narasumber yang menggunakan caption fenomenal Twitter memiliki tujuan yang hampir sama namun dengan pandangan yang berbeda-beda berdasarkan pada aktivitas yang mereka lakukan dan pengalaman yang mereka alami sendiri. Dapat dilihat bahwa para narasumber memaknai kehidupan ini dengan apa yang mereka alami secara langsung. Mereka berpikir bagaimana jika berada di posisi orang yang mereka tolong. Pikiran-pikiran inilah yang membuat mereka sadar bahwa rasa yang tulus dan ikhlas lahir begitu saja dalam benak mereka untuk meringankan beban orang-orang yang membutuhkan uluran tangan. Meskipun hal yang dilakukan terbilang kecil atau sederhana.

Data diambil menggunakan metode pengumpulan data fenomenologi. Pada penelitian ini digunakan teknik wawancara dengan narasumber, yang merupakan netizen Twitter yang menggunakan tagline Twitter yang fenomenal “Twitter, Please Do Your Magic!” dan berhasil mendapat perhatian dari netizen lainnya. Kebanyakan niat para netizen ini adalah murni karena mereka ingin membantu sesama dan dengan tujuan yang mulia pula. Namun, meski pendapat yang diperoleh dalam wawancara memiliki pandangan yang berbeda-beda dari sudut pandang masing-masing individu, tentu terdapat alasan tersendiri mengenai sebuah topik atau permasalahan yang ingin diangkat.

\section{KESIMPULAN}

Media sosial tidak hanya memberi dampak yang negatif bagi penggunanya, salah satunya yang terjadi pada media sosial Twitter, yang merupakan salah satu media sosial yang digunakan oleh netizen di Indonesia saat ini. Twitter mampu menjadi media sosial yang efektif dalam penyebaran informasi. Kreatifitas yang dilakukan oleh penggunanya, memunculkan sebuah kalimat ajaib atau caption fenomenal "Twitter, please do your magic!". Tagline ini sendiri memiliki makna bahwa Twitter mampu membuat sebuah cuitan menjadi viral dan diketahui lebih banyak pengguna Twitter, terkhusus bagi pengguna caption fenomenal Twitter yang menggunakannya untuk kegiatan yang positif, yaitu untuk membantu sesama manusia yang membutuhhkan bantuan. Dari hasil penelitian yang dilakukan, yaitu menggunakan netizen Twitter yang menggunakan caption fenomenal Twitter ini yang menjadi narasumber dalam penelitian ini, disimpulkan bahwa alasan penggunaan media sosial Twitter adalah karena penyebaran informasinya yang terbilang cepat.

Dorongan serta kepentingan muncul murni karena ingin membantu. Terlebih, netizen yang menjadi narasumber pada penelitian ini memilki respon yang baik, dan mendukung penuh aksi yang sangat positif ini sehingga dapat disimpulkan bahwa kepentingan dari penyebarluasan informasi menggunakan caption "Twitter, please do your magic!" semata-mata murni karena ingin membantu orang lain yang membutuhkan bantuan 
sehingga netizen Twitter terbilang terangsang dalam menggunakan media sosial Twitter sebagai media untuk ikut membantu orang lain yang membutuhkan tanpa mengenal siapa yang perlu ditolong.

\section{DAFTAR PUSTAKA}

Asosiasi Penyelenggaraan Jasa Internet Indonesia (APJII). (2018). Dikutip dari https://apjii.or.id Azexsharie, Azeharie, S, \& Kusuma, O. (2012). Analisis Pengguna Twitter sebagai Media Komunikasi Selebritis di Jakarta; Universitas Tarumanagara. Jakarta Barat. Dikutip dari https://journal.untar.ac.id/index.php/komunikasi/article/view/35

Detik.com. (2019). Kata Twitter Soal Twitter Please Do Your Magic. Dikutip dari https://m.detik.com/inet/cyberlife/d-4783146/kata-Twitter-soal-Twitter-do-your-magic

John, L \& Foss. (2009). Teori Komunikasi. Jakarta: Salemba Humanika.

Mulyana, D. (2004). Metode Penelitian Kualitatif Paradigma Baru Ilmu Komunikasi dan Ilmu Sosial Lainnya. Bandung: PT Remaja Rosdakarya.

Putra, N. (2013). Penelitian Kualitatif IPS. Bandung: PT. Remaja Rosdakarya Offset.

Tribunnews Jakarta. (2019). Viral wanita ini Temukan iPhone X di Stasiun Cikini, sosok Pemilik Ponsel Jadi Sorotan. Dikutip dari https://jakarta.tribunnews.com/amp/2019/08/15/ 